Gender differences show that women are significantly more stressed than men on nearly all measures, including time pressures, lack of personal time, household responsibilities, teaching loads, and subtle discrimination. However, subtle discrimination as a source of stress shows the greatest decline between 1989 and 1995, down 14 percent for women. While it is possible that efforts to improve the climate for women in academe have been effective, the fact still remains that 34 percent of women (compared with 18 percent of men) continue to experience stress from subtle discrimination.

Gender differences show that women
are significantly more stressed than men
on nearly all measures, including time
pressures, lack of personal time, house-
hold responsibilities, teaching loads,
and subtle discrimination.

Gender Differences in Salary Remain

Based on constant 1995-1996 dollars, U.S. faculty in 1995 earn somewhat less than they did in 1989. This trend is consistent with national declines in constant dollar salaries for workers in all occupations, as reported by the U.S. Bureau of the Census. Further, while gender differences in faculty salaries are smaller than gender differences in most other occupations, women faculty still earn approximately 80 percent of salaries earned by men. A gender gap in salaries remains even when salaries are adjusted to take women's typically lower academic rankings into account.

For additional information on the faculty survey or to order the 1995-1996 normative results, please write or call: Higher Education Research Institute, University of California, Los Angeles, Graduate School of Education and Information Studies, 3005 Moore Hall/Mailbox 951521, Los Angeles, CA 90095-1521. Tel: (310) 825-1925; fax: (310) 206-2228; Internet: HERI@gse.ucla.edu.

\section{Problems of Private Higher Education in Russia}

\section{Evgenii Kodin}

Evgenii Kodin is vice rector, Smolensk State Pedagogical Institute, 4, Przhevalskii St., Smolensk 214000, Russia. He has been a visiting scholar at the Center for International Higher Education, Boston College during 1996.

$\mathrm{O}$ ne of the most visible changes in the Russian system of higher education today, as well as in many other transitional or politically reforming countries, is the emergence of private educational institutions. There are more than 200 private universities in Russia now, with annual enrollments of over 60,000 students. What benefits have they offered to society, and what problems do they face?

Benefits

To begin with, private universities have satisfied a need in areas of study unavailable in public institutions-courses and degrees in management, business, market economy, and other related subjects that simply did not exist in the Russian curriculum until recently.

Second, the private sector has provided a crucial avenue of access to higher education for thousands of students whom public educational institutions could not accept because of the limits imposed by state-planned enrollment.

Third, private higher education has provided parents with a legal opportunity to invest money in their children's future.

Finally, these institutions - through their less traditional missions and pedagogical approaches-offer young and energetic people a chance to develop academic and organizational skills, as well as providing opportunities for self-realization and self-expression.

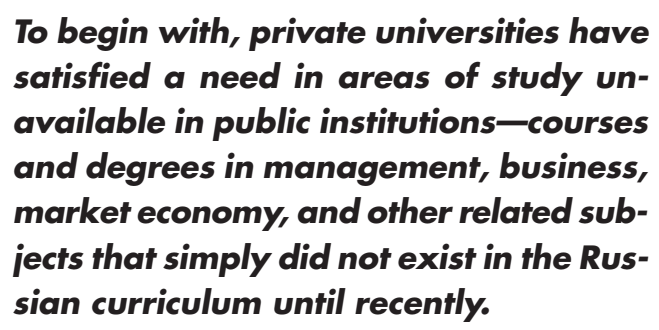

Some administrators of private universities admit now that they would never have entered the business of higher education if they had known the struggle they would face. 


\section{Problems}

Buildings. To open a university you need a building to house the academic process. Almost no Russian has enough money to construct a new university building, and so the only alternative is to rent space in someone else's building. Having rented a building - or parts of it - you can never be sure when your lease will expire and, if it does what to do next. Second, the building you have rented is not yours, to renovate, expand, or configure at will. As a result, none of the private Russian universities now have good buildings of their own-not to mention whole campuses.

Equipment. The problem of equipment and facilities is directly linked to the issue of buildings. Even with adequate resources to buy everything one needs, it is difficult to install equipment and means of communication-the landlord of the building may not allow it, the building might be too old to support the equipment, or a cable line needed for a voice-mail system may be unavailable just because it does not exist in the city.

Library. It is clear that there can be no serious academic process and research without a library. Do Russian private universities have their own libraries? No, they do not. They have neither enough books nor buildings to keep them in. It takes decades to build up a good university library. But this is not for Russia now. Students are being told that that they are responsible for finding the books they need for their classes.

\section{A large number of the faculty members at private universities are full-time em- ployees at public universities.}

Faculty. It is no problem for private universities to hire administrative and support staff, but it is very difficult to find professors to teach courses, particularly new ones. Specialists can be found in Moscow but not in other regions, so private rural universities have to attract visiting professors to their universities. These popular professors will usually come only if offered very high salaries-in comparison to local teachers-transportation, hotel, and board. Thus, bringing professors to teach at private universities becomes very expensive, and the most common result is an increase in tuition fees.

Another problem here is that visiting professors usually come not for a whole semester, but for two or three weeks only, and teach classes for 4-6 hours a day. These professors come with no course readings and sometimes give exams right after the course or one or two months later. All this leads to a very irregular organization of the educational process in the regional universities, which makes them unstable, unpredictable, and consequently less productive institutions.

A large number of the faculty members at private universities are full-time employees at public universities. They are employed as part-time staff in private institutions to teach general courses that every university is expected to offer. They are usually well-trained in their field and are not as "expensive" as the specialists. But a teacher involved in two universities may not have enough time for good preparation at either job. Consequently this situation has a negative effect on the quality of teaching in both private and public universities.

\section{Uncertainty is the most appropriate word to characterize the whole enter- prise of the private sector of Russian higher education today.}

Final document. What final document should be awarded to graduates of a private university today? Nobody can give you a definitive answer, and there is no answer in the Law on Education. A private university can award its own documents to its students only after it has been accredited to do so by the state, and accreditation cannot be provided before the institution has had at least three graduations.

The second aspect of this problem is similar to one that public universities have-what certificates to grant: diploma or degree? Having decided to follow a Western style of education-granting a bachelor's or master's degree-some private universities are in trouble now as to what such a degree means for their graduates in terms of future employment. Such degrees do not correspond with the realities and expectations of employers in the local job market.

\section{Conclusion}

Uncertainty is the most appropriate word to characterize the whole enterprise of the private sector of Russian higher education today. Uncertainty prevails in terms of renting buildings, hiring full-time faculty and visiting professors, developing the curriculum, awarding final documents to graduates, and so on. Furthermore, government politics are so unstable and unpredictable that no private university can feel absolutely independent-or really private. 